Finanse, Rynki Finansowe, Ubezpieczenia nr 2/2017 (86)

DOI: $10.18276 /$ frfu.2017.86-09

s. $111-122$

\title{
Długoterminowe reakcje cenowe na podziały akcji na Giełdzie Papierów Wartościowych w Warszawie
}

\author{
Szymon Okoń, Adam Zaremba*
}

\begin{abstract}
Streszczenie: $\mathrm{Cel}$ - Celem niniejszego artykułu jest zbadanie długoterminowych reakcji cenowych na podziały akcji na Giełdzie Papierów Wartościowych w Warszawie.

Metodologia badania - Badanie bazuje na podziałach akcji spółek notowanych na Giełdzie Papierów Wartościowych w Warszawie, które miały miejsce od stycznia 1996 roku do grudnia 2015 roku. W zakresie badania długoterminowych reakcji cenowych na podziały akcji w celu oceny stóp zwrotu wykorzystano metodę portfeli kalendarzowych (ang. calendar-time portfolio approach). W ramach badania metodą portfeli kalendarzowych skonstruowanych zostało osiem typów portfeli równoważonych i ważonych kapitalizacją z okresami utrzymywania akcji w portfelu wynoszącymi odpowiednio 1, 2, 3, 4, 5, 6, 7 i 8 lat. Nadwyżkowe stopy zwrotu zostały przetestowane przy wykorzystaniu dwóch modeli: modelu CAPM oraz czteroczynnikowego model Carharta, którego budowa obejmuje również wpływ efektów wielkości spółki oraz wskaźnika wartości księgowej do wartości rynkowej, a także efektu kontynuacji stóp zwrotu (ang. momentum).

Wynik - Nie zaobserwowano żadnych istotnych statystycznie ponadprzeciętnych stóp zwrotu bez względu na metody ważenia portfeli czy wykorzystane modele do oceny stóp zwrotu. Co istotne, w przypadku czteroczynnikowego modelu Carharta czynnik SMB (small minus big) pozostaje dodatni i istotny statystycznie we wszystkich okresach w przypadku portfeli równoważonych i w przypadku większości portfeli ważonych kapitalizacją, co może sugerować, że zainteresowanie splitami jest większe w przypadku spółek o mniejszej kapitalizacji.

Oryginalność/Wartość - Jest to pierwsze kompleksowe badanie reakcji cenowych na podziały akcji na Giełdzie Papierów Wartościowych w Warszawie.
\end{abstract}

Słowa kluczowe: split akcji, podział akcji, portfele kalendarzowe, analiza zdarzeń, długoterminowe reakcje cenowe, długoterminowe stopy zwrotu, Giełda Papierów Wartościowych w Warszawie, polski rynek akcji

\section{Wprowadzenie}

Podział akcji (split) wydaje się stosunkowo prostą czynnością korporacyjną, która nie powinna mieć istotnego znaczenia z punktu widzenia inwestorów. Ogólna liczba akcji spółki zwiększa się w zależności od przyjętego parytetu podziału akcji, natomiast ogólna wartość powinna pozostawać niezmienna, jako że operacja splitu nie ma na nią rzeczywistego

\footnotetext{
* dr Szymon Okoń, Uniwersytet Ekonomiczny w Poznaniu, Katedra Inwestycji i Rynków Kapitałowych, e-mail: szymon.okon@ue.poznan.pl; dr Adam Zaremba, Uniwersytet Ekonomiczny w Poznaniu, Katedra Inwestycji i Rynków Kapitałowych, e-mail: adam.zaremba@ue.poznan.pl

1 Badanie zostało sfinansowane z grantu Narodowego Centrum Nauki (2015/19/D/HS4/01950). „Decyzje finansowe w spółkach giełdowych na nieefektywnym rynku kapitałowym" (nr projektu DEC-2013/09/B/ HS4/01335).
} 
wpływu. Pojawia się bowiem więcej akcji spółki, przy czym ich cena jest odpowiednio niższa. Niemniej wiele dotychczasowych badań wykazało występowanie nadwyżkowych stóp zwrotu towarzyszących zjawisku podziału akcji. Przyczyny pojawiania się ponadprzeciętnych stóp zwrotu nie zostały do tej pory wyjaśnione, choć w literaturze można znaleźć wiele uzasadnień takiego stanu rzeczy.

Pierwsze z nich to sygnalizacja (ang. signalling hypothesis). Fama, Fisher, Jensen i Roll (1969) dowodzą, że splity stanowią dobre narzędzie do sygnalizowania, iż spółka w przyszłości może osiągać zyski i wypłacać dywidendę. Autorzy dowiedli, że 75\% firm spośród 940 w próbie badawczej zwiększyło wypłaty dla akcjonariuszy w okresie po podziale akcji. Asquith, Healy i Palepu (1989) zaobserwowali istnienie silnego wzrostu zysku przed splitem oraz umiarkowanego po podziale akcji. Zdaniem tych autorów, wystąpienie splitu prowadzi do sytuacji, w której inwestorzy oczekują, że wzrost zysku, jaki wystąpił przed podziałem, będzie miał charakter permanentny. Kalay i Kronlund (2014) potwierdzili, że splity mogą wskazywać na wzrost zysku w przyszłości.

Drugie z nich to zwiększenie atrakcyjności akcji z punktu widzenia rynkowego obrotu (ang. marketability) lub doprowadzenie ceny akcji do przedziału pożądanego przez inwestorów (McNichols, Dravid, 1990) (ang. trading range hipothesis). Niższa cena akcji może prowadzić do zwiększenia liczby inwestorów w spółce (Lamoureux, Poon 1987; Maloney, Mulherin, 1992). W związku z tym popyt na akcje może prowadzić do wzrostu wartości spółki. Takie podejście potwierdzają wyniki badań ankietowych przeprowadzonych przez Bakera i Gallaghera (1980). Jednak dalsze badania Lakonishok i Leva (1987) obejmujące historyczne stopy zwrotu prowadzą do odmiennych wniosków i zaprzeczają takiemu stanowi rzeczy, w szczególności w długim terminie.

Trzecie z nich to zwiększenie płynności (ang. liquidity). Dowodów na potwierdzenie, że podziały akcji prowadzą do zwiększenia płynności dostarczają w swoich badaniach Lakonishok i Lev (1987) oraz Lamoureux i Poon (1987). Część autorów zwraca jednak uwagę na to, że splitom towarzyszy jednocześnie zwiększenie spreadów transakcyjnych (Copeland, 1979; Kadapakkam, Krishnamurthy, Tse, 2005), co z kolei niekoniecznie prowadzi do wzrostu płynności.

Dotychczasowe badania nad długoterminowymi reakcjami cenowymi na zjawisko podziału akcji prezentują bardzo różne wnioski. Fama i in. (1969) przebadali 940 splitów akcji spółek notowanych na giełdzie nowojorskiej w okresie od stycznia 1927 do grudnia 1959 roku i nie zaobserwowali występowania istotnych ponadprzeciętnych nadwyżkowych stóp zwrotu w okresie 30 miesięcy po wystąpieniu zdarzenia. Do odmiennych rezultatów doprowadziły badania przeprowadzone przez Ikenberry'ego, Rankiego i Stice'a (1996) na rynku amerykańskim w okresie od 1975 do 1990 roku. Wykazali oni, że w ciągu roku po zdarzeniu średnia nadwyżkowa stopa zwrotu wniosła 7,9\%, natomiast w ciągu trzech lat $12,15 \%$. Występowanie długoterminowych pozytywnych reakcji cenowych na zjawisko podziału akcji potwierdzili również Desai i Jain (1997) w badaniach obejmujących rynek amerykański w latach 1976-1991. Autorzy przebadali 5596 splitów i zaobserwowali nadwyżkową stopę zwrotu na poziomie $7,05 \%$ po roku od ogłoszenia zdarzenia i $11,87 \%$ po trzech 
latach. W późniejszym czasie podobne badania przeprowadzili również Chen, Kim i Xu. Przeanalizowali podziały akcji na rynku amerykańskim w latach 1931-1990 i dowiedli, że spółki, które dokonywały splitów, osiągają nadwyżkową stopę zwrotu na poziomie 5,10\% w przypadku spółek o podobnej kapitalizacji (ang. side-matched firms) oraz 4,62\% w przypadku firm o podobnej becie (ang. beta-matched firms). Jeszcze szersze badania, również na rynku amerykańskim, przeprowadzili Byun i Rozeff (2003). Zweryfikowali długoterminowe reakcje cenowe na podziały akcji w latach 1927-1996 w próbie badawczej obejmującej 12747 splitów, wykorzystując dwie metody mierzenia nadwyżkowych stóp zwrotu: portfele oparte na wielkości i wskaźniku wartości księgowej do wartości rynkowej oraz portfele kalendarzowe połączone z modelami wielkoczynnikowymi. W pierwszym przypadku w niektórych podokresach badania autorzy uzyskali pozytywne nadwyżkowe stopy zwrotu towarzyszące długoterminowym reakcjom cenowym na splity, natomiast w przypadku portfeli kalendarzowych pozostawały one na niskim lub pomijalnym poziomie.

Różnice w prezentowanych dotychczas wynikach badań mogą wynikać z różnych okresów badania, jak również stosowanej metodologii. Niektóre badania wykorzystują bowiem modele wieloczynnikowe i efekty wielkości czy wskaźnika wartości księgowej do wartości rynkowej, a w części z nich stosuje się jeszcze inne podejścia. Warto zauważyć, że większość badań odnosi się do rynku amerykańskiego, nie ma natomiast kompleksowych opracowań, które obejmowałyby rynki wschodzące. Z tego względu w niniejszym artykule zdecydowano się na przeprowadzenie badań dotyczących długoterminowych reakcji cenowych na podziały akcji na rynku polskim w latach 1996-2015, wykorzystując nowatorskie narzędzia, które będą mogły zostać zaaplikowane do dalszych badań w tym zakresie także na innych rynkach.

W ramach niniejszego badania nie zaobserwowano żadnych istotnych statystycznie ponadprzeciętnych stóp zwrotu bez względu na metody ważenia portfeli. Należy jednak zwrócić uwagę na występowanie najwyższych dodatnich statystycznie nieistotnych ponadprzeciętnych długoterminowych stóp zwrotu po podziale akcji na Giełdzie Papierów Wartościowych w Warszawie w przypadku portfeli z dwuletnim okresem utrzymywania po wystąpieniu zdarzenia. Co istotne, w przypadku modelu czteroczynnikowego czynnik SMB (small minus big) pozostaje dodatni i istotny statystycznie we wszystkich okresach w przypadku portfeli równoważonych, co może sugerować, że zainteresowanie splitami jest większe w przypadku spółek o mniejszej kapitalizacji.

Struktura artykułu jest następująca. W pierwszej części opisano dane źródłowe i metody badawcze. W części drugiej przedstawiono uzyskane wyniki badań. Całość pracy została zwieńczona podsumowaniem (uwagi końcowe).

\section{Dane źródłowe i metody badawcze}

W niniejszym artykule badaniu poddane zostało zjawisko długoterminowych ponadprzeciętnych stóp zwrotu po podziałach akcji na Giełdzie Papierów Wartościowych w Warszawie. 
Badanie dotyczy splitów w latach 1996-2015. Weryfikacji poddano hipotezę, że spółki, które dokonywały podziałów akcji, nie notowały długookresowych ponadprzeciętnych stóp zwrotu.

W niniejszej części w pierwszej kolejności omówione zostaną dane źródłowe wykorzystane w badaniu, a następnie metody analizy stóp zwrotu po splitach.

\section{1. Źródla i przygotowanie danych}

Prezentowane badanie bazowało na podziałach akcji spółek notowanych na Giełdzie Papierów Wartościowych w Warszawie, które miały miejsce od stycznia 1996 do grudnia 2015 roku. Lista splitów została skompilowana na postawie dwóch źródeł: bazy danych systemu Bloomberg oraz serwisu Bossa.pl ${ }^{2}$, i przedstawiona w załączniku (tab. A1).

Zasadnicza analiza stóp zwrotu obejmuje okres od marca 2000 do stycznia 2016 roku. Późny początek stop zwrotu wynikał z dwóch kwestii: 1) konstrukcji portfeli, które uwzględniały podziały akcji sprzed kilku lat; 2) dostępności portfeli czynnikowych wykorzystywanych w modelach wyceny. Spółka była uwzględniana w próbie, gdy możliwe było jej wyznaczenie kapitalizacji na koniec miesiąca $t$-1 oraz stopy zwrotu w miesiącu. Jako stopę zwrotu wolną od ryzyka wykorzystano średnią z 1-miesięcznych stawek WIBOR i WIBID.

\subsection{Ocena dlugoterminowych stóp zwrotu}

W celu oceny stop zwrotu po podziałach akcji wykorzystano metodę portfeli kalendarzowych (ang. calendar-time portfolio approach). Pisząc pokrótce, można wyjaśnić, że podejście to zakłada budowę portfeli, w których spółki utrzymywane są przez określony czas po wystąpieniu na rynku analizowanego zdarzenia, a następnie ocenę ich stóp zwrotu za pomocą modeli wyceny aktywów. Metoda ta została po raz pierwszy zaproponowana przez Jaffe'a (1974) i Mandelkera (1974). Wykorzystanie portfeli kalendarzowych jest postrzegane jako właściwa w długoterminowej analizie zdarzeń, minimalizuje bowiem problem braku stabilności parametrów w czasie, a także odzwierciedla perspektywę inwestora ${ }^{3}$.

W ramach badania metodą portfeli kalendarzowych skonstruowano osiem typów portfeli z okresami utrzymywania akcji w portfelu wynoszącymi odpowiednio 1, 2, 3, 4, 5, 6, 7 i 8 lat (12, 24, 36, 48, 60, 72, 84 i 96 miesięcy kalendarzowych). Spółki firm dokujących podziału swoich akcji były włączane do portfela w ostatnim dniu miesiąca, po którym nastąpił split, oraz z niego wykluczane po upływie odpowiednio od 12 do 96 miesięcy. Stopy zwrotu z portfeli obliczono dwójnasób: przy założeniu, że portfele są równoważone oraz że są one

\footnotetext{
2 http://bossa.pl/analizy/splity/.

3 W odniesieniu do polskiego rynku akcji podejście to zostało dotychczas wykorzystane m.in. przez Szyszkę i Zarembę (2011) do oceny odpowiednio długoterminowych reakcji cenowych na skupy akcji własnych oraz przez Zarembę i Płotnickiego (2015) do oceny wpływu ogłoszeń o transakcjach fuzji i przejęć.
} 
ważone kapitalizacją poszczególnych spółek. Wykorzystanie dwóch różnych podejść miało na celu uzyskanie większej odporności wyników. Na potrzeby wnioskowania statystycznego, obliczono także nadwyżkowe stopy zwrotu ponad 1-miesięczną stopę WIBOR (średnia z ofert bid i ask).

Nadwyżkowe stopy zwrotu zostały następnie przetestowane przy wykorzystaniu dwóch modeli. Pierwszy był klasyczny Model Wyceny Aktywów Kapitałowych (ang. Capital Asset Pricing Model, CAPM) zaproponowany m.in. przez Sharpe'a (1966). Drugi to czteroczynnikowy model Carharta (1997), którego budowa obejmuje również wpływ efektów wielkości spółki oraz wskaźnika wartości księgowej do rynkowej, a także efektu kontynuacji stóp zwrotu (ang. momentum). Szczegółową charakterystykę obu modeli oraz weryfikację zasadności ich zastosowania na polskim rynku akcji można znaleźć w pracach Waszczuk (2013), Zaremby (2014) oraz Czapkiewicz i Wojtowicza (2014).

Parametry wszystkich modeli szacowano przy pomocy klasycznej metody najmniejszych kwadratów na podstawie szeregów czasowych o miesięcznych interwałach. Dane w zakresie stóp zwrotu z portfeli czynnikowych pozyskano ze strony Adama Zaremby ${ }^{4}$. Hipoteza zerowa testowana w odniesieniu do długoterminowych ponadprzeciętnych stóp zwrotu brzmiała, że wyrazy wolne z modeli nie są istotnie różne od zera, wobec hipotezy alternatywnej, że są one różne. Statystyki testowe na potrzeby hipotez obliczane były metodą bootstrap przy wykorzystaniu 10000 losowań.

\section{Wyniki badań}

W tabeli 1 przedstawiono dane statystyczne dotyczące długoterminowych ponadprzeciętnych stóp zwrotu z odpowiednio równoważonych i ważnych kapitalizacją portfeli kalendarzowych spółek, które przeprowadziły podziały swoich akcji. Dane zostały zaprezentowane w odniesieniu do wszystkich ośmiu portfeli z okresami utrzymywania akcji w portfelu wynoszącymi odpowiednio 1, 2, 3, 4, 5, 6, 7 i 8 lat. Jak można zauważyć, liczba splitów w poszczególnych portfelach wzrasta wraz ze wzrostem okresu utrzymywania akcji w danym portfelu. Średnie nadwyżkowe stopy zwrotu z równoważonych portfeli kalendarzowych pozostają dodatnie i nieistotne statystycznie w przypadku każdego portfela, przy czym najwyższą stopę zwrotu odnotował portfel z dwuletnim okresem utrzymywania. Wskaźniki Sharpe’a pozostają dodatnie, przy czym są bliskie zeru. W przypadku portfeli ważonych kapitalizacją średnie nadwyżkowe stopy zwrotu są co do zasady ujemne, z wyłączeniem portfela z dwuletnim okresem utrzymywania, oraz nieistotne statystycznie. Wskaźniki Sharpe’a dla każdego portfela pozostają ujemne, $\mathrm{z}$ wyłączeniem portfela z dwuletnim okresem utrzymywania, gdy wskaźnik Sharpe’a jest dodatni, ale bliski zeru. W przypadku ujemnych wartości oznacza to, że portfele uzyskały stopy zwrotu niższe niż stopa wolna od ryzyka. W odniesieniu do zmienności można zauważyć zależność, że począwszy od portfela z okresem utrzymywania

4 http://adamzaremba.pl/downloadable-data/ (dostęp 14.02.2016). 
akcji równym dwa lata co do zasady, zmienność maleje wraz ze wzrostem okresu utrzymywania akcji w portfelu. Portfele równoważone cechują się lewoskośnością, czego nie można jednoznacznie stwierdzić w odniesieniu do portfeli ważonych kapitalizacją - tam w portfelach obejmujących okres jednego roku mamy do czynienia z prawoskośnością, w przypadku okresu dwóch i trzech lat występuje lewoskośność, a w pozostałym zakresie mamy do czynienia z asymetrią bliską zeru.

\section{Tabela 1}

Długoterminowe nadwyżkowe stopy zwrotu z portfeli kalendarzowych

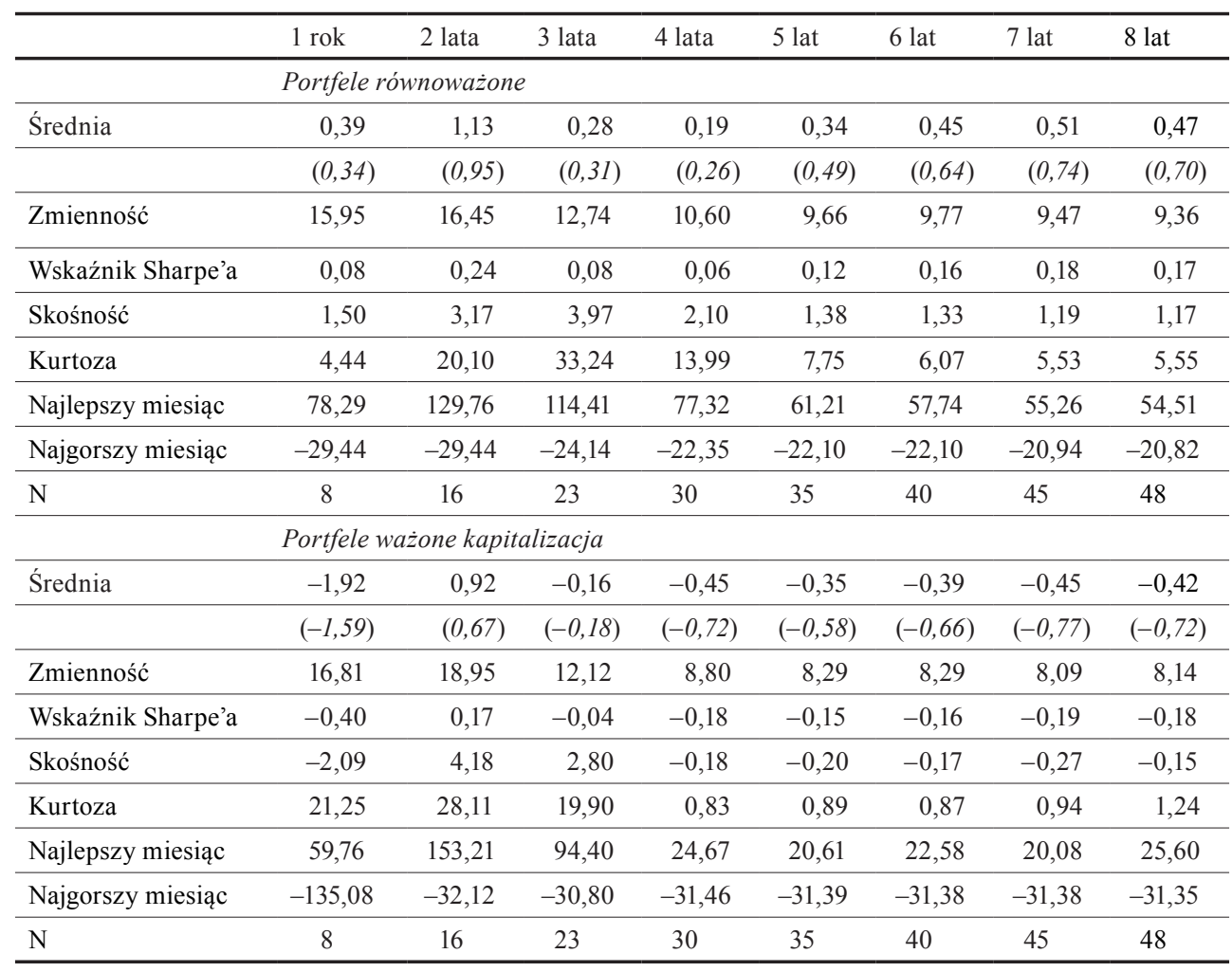

Uwagi: W tabeli przedstawiono podstawowe statystki dotyczące miesięcznych logarytmicznych nadwyżkowych stop zwrotu z portfeli kalendarzowych. Nagłówki kolumn wskazują okresy formowania portfeli kalendarzowych. „Zmienność” - odchylenie standardowe, „N”- średniomiesięczna liczba spółek w portfelu. Wskaźnik Sharpe"a jest zaprezentowany w postaci zannualizowanej. Średnia, zmienność oraz stopy zwrotu w miesiącach skrajnych zostały wyrażone w procentach. Wartości w nawiasach wskazują statystyki $t$. Wartości istotnie różne od 0 na poziomie istotności 5\% i 1\% zostały oznaczone odpowiednio * i **.

Źródło: opracowanie własne na podstawie na danych z systemu Bloomberg.

W tabeli 2 przedstawiono skumulowane długoterminowe ponadprzeciętne stopy zwrotu według modelu CAPM z odpowiednio równoważonych i ważnych kapitalizacją portfeli kalendarzowych spółek, które przeprowadziły podziały swoich akcji. Strategie bazujące na 
portfelach z okresami utrzymywania akcji w portfelu odpowiednio 1, 2, 3, 4, 5, 6, 7 i 8 lat (12, 24, 36, 48, 60, 72, 84 i 96 miesięcy kalendarzowych) zostały porównane z wynikami indeksu WIG. Jak można zauważyć, w przypadku portfeli równoważonych w każdym portfelu obserwuje się ponadprzeciętne stopy zwrotu, przy czym w porównaniu do indeksu szerokiego rynku w Polsce nie są to istotne różnice. Inaczej jest jednak w przypadku portfeli ważonych kapitalizacją. W pierwszym roku po podziale akcji występuje ujemna ponadprzeciętna stopa zwrotu, w portfelu z dwuletnim okresem utrzymywania pojawia się dodatnia znacząca nadwyżkowa stopa zwrotu, a w pozostałych mamy do czynienia z ponadprzeciętnymi stopami zwrotu, które oscylują blisko zera (zarówno dodatnie, jak i ujemne). Wszystkie portfele wykazują wyraźną ekspozycję na ryzyko rynkowe, a bety są bliskie 1. Podsumowując, przedstawione wyniki sugerują, że w portfelu z dwuletnim okresem utrzymywania po wystąpieniu splitu spółki osiągają najwyższe z wszystkich portfeli nadwyżkowe stopy zwrotu, przy czym ze względu na brak istotności statystycznej wyniki nie są rozstrzygające.

\section{Tabela 2}

Ponadprzeciętne stopy zwrotu z portfeli kalendarzowych według modelu CAPM

\begin{tabular}{|c|c|c|c|c|c|c|c|c|}
\hline & 1 rok & 2 lata & 3 lata & 4 lata & 5 lat & 6 lat & 7 lat & 8 lat \\
\hline \multicolumn{9}{|c|}{ Portfele równoważone } \\
\hline \multirow[t]{2}{*}{$\alpha$} & 0,61 & 1,37 & 0,51 & 0,44 & 0,59 & 0,70 & 0,76 & 0,72 \\
\hline & $(0,55)$ & $(1,23)$ & $(0,62)$ & $(0,70)$ & $(1,08)$ & $(1,29)$ & $(1,45)$ & $(1,42)$ \\
\hline \multirow[t]{3}{*}{$R_{m}-R_{f}$} & $0,85 * *$ & $0,96 * *$ & $0,91 * *$ & $0,98 * *$ & $0,98 * *$ & $1,00 * *$ & $0,99 * *$ & $0,99 * *$ \\
\hline & $(4,90)$ & $(5,39)$ & $(6,90)$ & $(9,73)$ & $(11,25)$ & $(11,45)$ & $(11,89)$ & $(12,22)$ \\
\hline & \multicolumn{8}{|c|}{ Portfele ważone kapitalizacja } \\
\hline \multirow[t]{2}{*}{$\alpha$} & $-1,70$ & 1,18 & 0,12 & $-0,17$ & $-0,07$ & $-0,11$ & $-0,17$ & $-0,14$ \\
\hline & $(-1,47)$ & $(0,92)$ & $(0,17)$ & $(-0,44)$ & $(-0,21)$ & $(-0,34)$ & $(-0,55)$ & $(-0,46)$ \\
\hline \multirow[t]{2}{*}{$R_{m}-R_{f}$} & $0,87 * *$ & $1,05 * *$ & $1,09 * *$ & $1,11 * *$ & $1,08 * *$ & $1,09 * *$ & $1,10 * *$ & $1,11 * *$ \\
\hline & $(4,69)$ & $(5,10)$ & $(9,37)$ & $(17,73)$ & $(19,41)$ & $(20,08)$ & $(22,06)$ & $(22,32)$ \\
\hline
\end{tabular}

Uwagi: W tabeli przedstawiono ponadprzeciętne stopy zwrotu z portfeli kalendarzowych według modelu CAPM. Nagłówki kolumn wskazują okresy formowania portfeli kalendarzowych. Wartości w nawiasach wskazują statystyki $t$. Wartości istotnie różne od 0 na poziomie istotności $5 \%$ i $1 \%$ zostały oznaczone odpowiednio $* \mathrm{i} * *$. Wartości istotnie różne od 0 na poziomie istotności $5 \%$ zostały dodatkowo wytłuszczone. $\alpha$ - wyraz wolny z modelu, $\mathrm{R}_{\mathrm{m}}{ }^{-}{ }_{\mathrm{Rf}}-$ czynnik ryzyka rynkowego.

Źródło: opracowanie własne na podstawie na danych z systemu Bloomberg.

W tabeli 3 przedstawiono skumulowane długoterminowe ponadprzeciętne stopy zwrotu według modelu czteroczynnikowego z odpowiednio równoważonych i ważnych kapitalizacją portfeli kalendarzowych spółek, które przeprowadziły podziały swoich akcji. W przypadku modelu czteroczynnikowego obserwuje się podobne zachowania ponadprzeciętnych stóp zwrotu jak w przypadku modelu CAPM. W zakresie długoterminowych reakcji cenowych na podziały akcji po wystąpieniu splitu, mając na względzie wyniki uzyskane z portfeli kalendarzowych przy zastosowaniu modelu czteroczynnikowego, można stwierdzić, 
że badania te pozostają spójne z ustaleniami poczynionymi przez Byuna i Rozeffa (2003) na rynku amerykańskim, uwzględniając splity w latach 1927-1996.

Włączenie dodatkowych zmiennych do modelu nie zmienia istotnie spojrzenia na wyniki. Czynnik SMB (small minus big) pozostaje dodatni i istotny statystycznie we wszystkich okresach w przypadku portfeli równoważonych i w większości portfeli ważonych kapitalizacją, co może sugerować, że zainteresowanie splitami jest większe w przypadku spółek małych. Natomiast czynniki HML (high minus low) oraz WML (winners minus losers) są nieistotne statystycznie. Tym samym można uznać, że wskaźnik wartości księgowej do wartości rynkowej (BV/MV), jak również efekt momentum nie wpływają na występowanie długoterminowych nadwyżkowych stóp zwrotu w związku z podziałami akcji.

\section{Tabela 3}

Ponadprzeciętne stopy zwrotu z portfeli kalendarzowych według modelu czteroczynnikowego

\begin{tabular}{|c|c|c|c|c|c|c|c|c|}
\hline & $1 \mathrm{rok}$ & 2 lata & 3 lata & 4 lata & 5 lat & 6 lat & 7 lat & 8 lat \\
\hline \multicolumn{9}{|c|}{ Portfele równoważone } \\
\hline \multirow[t]{2}{*}{$\mathrm{a}$} & 0,84 & 1,23 & 0,44 & 0,26 & 0,38 & 0,58 & 0,61 & 0,60 \\
\hline & $(0,74)$ & $(1,07)$ & $(0,51)$ & $(0,42)$ & $(0,74)$ & $(1,12)$ & $(1,26)$ & $(1,27)$ \\
\hline \multirow[t]{2}{*}{$R_{m}-R_{f}$} & $0,93 * *$ & $1,03 * *$ & $0,97 * *$ & $1,05 * *$ & $1,04 * *$ & $1,07 * *$ & $1,06 * *$ & $1,06 * *$ \\
\hline & $(5,29)$ & $(5,76)$ & $(7,42)$ & $(10,91)$ & $(12,93)$ & $(13,37)$ & $(14,19)$ & $(14,58)$ \\
\hline \multirow[t]{2}{*}{ SMB } & $0,51^{*}$ & $0,58 *$ & $0,58 * *$ & $0,67 * *$ & $0,68 * *$ & $0,70 * *$ & $0,73 * *$ & $0,72 * *$ \\
\hline & $(2,14)$ & $(2,41)$ & $(3,29)$ & $(5,14)$ & $(6,26)$ & $(6,45)$ & $(7,20)$ & $(7,28)$ \\
\hline \multirow[t]{2}{*}{ HML } & $-0,30$ & $-0,04$ & $-0,03$ & 0,04 & 0,08 & 0,00 & 0,03 & 0,02 \\
\hline & $(-1,20)$ & $(-0,17)$ & $(-0,14)$ & $(0,29)$ & $(0,68)$ & $(0,00)$ & $(0,26)$ & $(0,24)$ \\
\hline \multirow[t]{3}{*}{ WML } & $-0,12$ & 0,06 & 0,00 & 0,04 & 0,04 & 0,01 & 0,01 & $-0,01$ \\
\hline & $(-0,54)$ & $(0,29)$ & $(-0,02)$ & $(0,38)$ & $(0,39)$ & $(0,10)$ & $(0,09)$ & $(-0,12)$ \\
\hline & \multicolumn{8}{|c|}{ Portfele ważone kapitalizacja } \\
\hline \multirow[t]{2}{*}{$\alpha$} & $-2,05$ & 0,88 & 0,07 & $-0,25$ & $-0,20$ & $-0,25$ & $-0,32$ & $-0,24$ \\
\hline & $(-1,69)$ & $(0,64)$ & $(0,09)$ & $(-0,63)$ & $(-0,57)$ & $(-0,73)$ & $(-1,03)$ & $(-0,77)$ \\
\hline \multirow[t]{2}{*}{$R_{m}-R_{f}$} & $0,92 * *$ & $1,09 * *$ & $1,12 * *$ & $1,15 * *$ & $1,11 * *$ & $1,13 * *$ & $1,13 * *$ & $1,14 * *$ \\
\hline & $(4,92)$ & $(5,18)$ & $(9,50)$ & $(18,42)$ & $(20,12)$ & $(21,29)$ & $(23,70)$ & $(24,08)$ \\
\hline \multirow[t]{2}{*}{ SMB } & 0,29 & 0,30 & 0,22 & $0,26 * *$ & $0,24 * *$ & $0,29 * *$ & $0,31 * *$ & $0,32 * *$ \\
\hline & $(1,14)$ & $(1,05)$ & $(1,39)$ & $(3,08)$ & $(3,24)$ & $(4,12)$ & $(4,87)$ & $(4,93)$ \\
\hline \multirow[t]{2}{*}{ HML } & 0,03 & 0,10 & $-0,06$ & $-0,03$ & 0,02 & 0,02 & 0,04 & 0,00 \\
\hline & $(0,10)$ & $(0,35)$ & $(-0,34)$ & $(-0,31)$ & $(0,24)$ & $(0,22)$ & $(0,58)$ & $(0,04)$ \\
\hline \multirow[t]{2}{*}{ WML } & 0,26 & 0,18 & 0,05 & 0,05 & 0,07 & 0,07 & 0,06 & 0,04 \\
\hline & $(1,13)$ & $(0,68)$ & $(0,33)$ & $(0,65)$ & $(1,06)$ & $(1,06)$ & $(1,07)$ & $(0,60)$ \\
\hline
\end{tabular}

Uwagi: W tabeli przedstawiono ponadprzeciętne stopy zwrotu z portfeli kalendarzowych według modelu czteroczynnikowego. Nagłówki kolumn wskazują okresy formowania portfeli kalendarzowych. Wartości w nawiasach wskazują statystyki $t$. Wartości istotnie różne od 0 na poziomie istotności 5\% i 1\% zostały oznaczone odpowiednio * i **. Wartości istotnie różne od 0 na poziomie istotności 5\% zostały dodatkowo wytłuszczone. $\alpha$-wyraz wolny z modelu, $\mathrm{R}_{\mathrm{m}}{ }_{\mathrm{Rf}}$ - czynnik ryzyka rynkowego, $\mathrm{SMB}$ to - small minus big, $\mathrm{HML}$ - high minus low, WML-winners minus losers. Źródło: opracowanie własne na podstawie na danych z systemu Bloomberg. 
W ramach niniejszego badania nie zaobserwowano żadnych istotnych statystycznie ponadprzeciętnych stóp zwrotu bez względu na metody ważenia portfeli. Należy jednak zwrócić uwagę na występowanie najwyższych dodatnich statystycznie nieistotnych ponadprzeciętnych długoterminowych stóp zwrotu po podziale akcji na Giełdzie Papierów Wartościowych w Warszawie w portfelu z dwuletnim okresem utrzymywania po wystąpieniu zdarzenia. Co istotne, w przypadku modelu czteroczynnikowego czynnik SMB (small minus big) pozostaje dodatni i istotny statystycznie we wszystkich okresach w przypadku portfeli równoważonych i w większości portfeli ważonych kapitalizacją, co może sugerować, że zainteresowanie splitami jest większe w przypadku spółek o mniejszej kapitalizacji.

\section{Uwagi końcowe}

Zjawisko długoterminowych reakcji cenowych na podziały akcji doczekało się wielu badań na rynku amerykańskim, które nie prowadzą jednak do jednoznacznych wniosków. Brak analiz w tym zakresie na rynkach wschodzących, w szczególności na Giełdzie Papierów Wartościowych w Warszawie, skłoniły autorów do przeprowadzenia niniejszych badań.

Zgodnie z przedstawionymi wynikami nie zaobserwowano istotnych statystycznie ponadprzeciętnych stóp zwrotu bez względu na metody ważenia portfeli (portfele równoważone i portfele ważone kapitalizacją) czy wykorzystane modele do oceny stóp zwrotu (model CAPM oraz model czteroczynnikowy). Należy jednak zwrócić uwagę na występowanie najwyższych dodatnich statystycznie nieistotnych ponadprzeciętnych długoterminowych stóp zwrotu po podziale akcji na Giełdzie Papierów Wartościowych w Warszawie w portfelu $\mathrm{z}$ dwuletnim okresem utrzymywania po wystąpieniu zdarzenia. Co istotne, w przypadku czteroczynnikowego modelu Carharta czynnik SMB (small minus big) pozostaje dodatni i istotny statystycznie we wszystkich okresach w przypadku portfeli równoważonych i w przypadku większości portfeli ważonych kapitalizacją, co może sugerować, że zainteresowanie splitami jest większe w przypadku spółek o mniejszej kapitalizacji. W odniesieniu do długoterminowych reakcji cenowych na podziały akcji po wystąpieniu splitu, mając na względzie wyniki uzyskane z portfeli kalendarzowych przy zastosowaniu modelu czteroczynnikowego, można stwierdzić, że badania te pozostają spójne z ustaleniami poczynionymi przez Byuna i Rozeffa (2003) na rynku amerykańskim w latach 1927-1996.

W pracy wykorzystano nowatorskie narzędzia. W celu oceny stóp zwrotu zastosowano metodę portfeli kalendarzowych (ang. calendar-time portfolio approach). Skonstruowano portfele równoważone i ważone kapitalizacją z odpowiednimi okresami utrzymywania akcji. Nadwyżkowe stopy zwrotu przetestowano przy wykorzystaniu dwóch modeli: modelu CAPM oraz czteroczynnikowego model Carharta, którego budowa obejmuje również wpływ efektów wielkości spółki oraz wskaźnika wartości księgowej do rynkowej, a także efektu kontynuacji stóp zwrotu (ang. momentum). Zastosowane narzędzia będą mogły zostać zaaplikowane do dalszych badań w tym zakresie także na innych rynkach. 
Wnioski z przeprowadzonych badań mogą być obarczone potencjalnie następującymi ograniczeniami. Po pierwsze, zakres czasowy badania jest relatywnie krótki i obejmuje lata globalnego kryzysu finansowego, co może zniekształcić uzyskane wyniki. Uzyskanie dłuższych szeregów czasowych w obecnej chwili nie jest jednak możliwe. Rezultaty mogą być w pewnej mierze specyficzne dla danego okresu. Po drugie, próba badawcza wykorzystana w badaniu jest niewielka. Po trzecie, w badaniu nie uwzględniono kosztów transakcyjnych ani ograniczeń płynności.

Dalsze badania w tym zakresie mogą odbywać się co najmniej w dwóch kierunkach. Po pierwsze, jedną z wad przeprowadzonych obliczeń jest pominięcie funkcji kosztów oraz ograniczeń płynności. Tym samym kwestie te można byłoby uwzględnić w dalszych badaniach, w szczególności z tego względu, że mogą one wyjaśniać opisywane efekty. Po drugie, cenne byłoby również przyjrzenie się kształtowaniu się długoterminowych nadwyżkowych stóp zwrotu w odniesieniu do zdarzeń odwrotnych do splitów, a mianowicie do scalenia akcji.

\section{Literatura}

Asquith, P., Healy, P., Palepu, K. (1989). Earnings and Stock Splits. The Accounting Review, 64 (3), 387-403. Baker, K.H., Gallagher, P.L. (1980). Management's View of Stock Splits. Financial Management, 9 (2), $73-77$. Buyn, J., Rozeff, M.S. (2003). Long-Run Performance after Stock Splits: 1927 to 1996. The Journal of Finance, $58(3), 1063-1085$.

Carhart, M.M. (1997). On persistence in mutual fund performance. Journal of Finance, 52, 57-82.

Chen, K.C., Kim, S., Xu, P.H. Long-term performance after Stock Splits: A Closer Look. Working paper. Pobrano z: http://condor.depaul.edu/afatemi1/Split.doc (28.05.2016).

Copeland, T. (1979). Liquidity Changes following Stock Splits. Journal of Finance, 34 (1), 115-141.

Czapkiewicz, A., Wojtowicz, T. (2014). The four-factor asset pricing model on the Polish stock market. Economic Research - Ekonomska Istraživanja, 27 (1), 771-783.

Desai, H., Jain, P.C. (1997). Long-Run Common Stock Returns following Stock Splits and Reverse Splits. The Journal of Business, 70 (3), 409-433.

Fama, E.F., Fisher, L., Jensen, M.C., Roll, R. (1969). The adjustment of stock prices to new information. International Economic Review, 10 (1), 1-21.

Ikenberry, D.L., Rankie, G., Stice, E.K. (1996). What Do Stock Splits Really Signal? Journal of Financial and Quantitative Analysis, 31 (3), 357-375.

Jaffe, J.F. (1974). Special information and insider trading. Journal of Business, 47, 410-428.

Kadapakkam, P.R., Krishnamurthy, S., Tse, Y. (2005). Stock Splits, Broker Promotion, and Decimalization. The Journal of Financial and Quantitative Analysis, 40 (3), 873-895.

Kalay, A., Kronlund, M. (2014). The Market Reaction to Stock Split Announcements: Eearnings Information After All. Pobrano z: http://ssrn.com/abstract=1027543 (28.05.2016).

Lakonishok, J., Lev, B. (1987). Stock Splits and Stock Dividends: Why, Who, and When. Journal of Finance, 49 (4), 913-932.

Lamoureux, C., Poon, P. (1987). The Market Reaction to Stock Splits. Journal of Finance, 62 (4), 1347-1370.

MacNichols, M., Dravid, A. (1990). Stock Dividends, Stock Splits, and Signaling. Jornal of Finance, 45 (3), 857-879.

Maloney, M., Mulherin, J. (1992). The Effects of Splitting on the Ex: A Microstructure Reconciliation. Financial Management, 21 (4), 40-59.

Mandelker, G. (1974). Risk and return: The case of merging firms. Journal of Financial Economics, 1 (4), 303-335. 
Sharpe, W.F. (1966). Mutual fund performance. Journal of Business, 39, 119-138.

Szyszka, A., Zaremba, A. (2011). The buyback anomaly in the Polish capital market. Zeszyty Naukowe Uniwersytetu Szczecińskiego, 640. Finanse, Rynki Finansowe, Ubezpieczenia, 38, 481-493.

Waszczuk, A. (2013). A risk-based explanation of return patterns - evidence from the Polish stock market. Emerging Markets Review, 15, 186-210.

Zaremba, A. (2014). Cross-sectional asset pricing models for the Polish market. Pobrano z: http://ssrn.com/abstract=2396884 or http://dx.doi.org/10.2139/ssrn.2396884 (14.02.2016).

Zaremba, A., Płotnicki, M. (2015). Krótkoterminowe i długoterminowe reakcje cenowe na ogłoszenia transakcji fuzji i przejęć na rynkach Europy Środkowo-Wschodniej. Zeszyty Naukowe Uniwersytetu Szczecińskiego, 854. Finanse, Rynki Finansowe, Ubezpieczenia, 73, 593-606.

\section{Załącznik}

\section{Tabela A1}

Lista splitów objętych badaniem

\begin{tabular}{|c|c|c|c|c|c|}
\hline Data & ISIN & Data & ISIN & Data & ISIN \\
\hline 1 & 2 & 3 & 4 & 5 & 6 \\
\hline 1996-01-25 & PLOKOCM00018 & $2007-08-16$ & PLPRCAD00018 & $2011-11-22$ & PLLENTX00010 \\
\hline 1996-07-08 & PLANIMX00019 & $2007-08-27$ & PLPEPES00018 & 2011-12-22 & PLLANGL00010 \\
\hline 1996-09-30 & PLRLMPX00012 & $2007-08-28$ & PLORZEL00017 & $2012-01-27$ & PLPNTCR00017 \\
\hline 1996-10-15 & PLIRENA00018 & 2007-09-06 & PLIMPXM00019 & 2012-03-14 & PLHRDEX00021 \\
\hline 1997-03-21 & PLKETY000011 & 2007-09-07 & PLVSTLA00011 & 2012-04-30 & PLPNCNR00010 \\
\hline 1997-04-17 & PLCHSKR00012 & 2007-09-20 & PLMSTSD00019 & 2012-05-18 & PLPSTBX00016 \\
\hline 1998-07-15 & PLPERMD00019 & 2007-09-24 & PLPEMUG00016 & $2012-05-21$ & PLHOTB000011 \\
\hline 1998-08-15 & PLCRSNT00011 & $2007-11-15$ & PLDWORY00019 & 2012-09-18 & PLATCDL00013 \\
\hline $1998-08-26$ & PLGRBRN00012 & $2007-11-22$ & PLMEWA000012 & $2012-10-29$ & PLELKPE00014 \\
\hline 1999-01-16 & PLBFKBL00017 & 2008-01-02 & PLECHPS00019 & $2012-12-13$ & PLPAR0000010 \\
\hline 1999-06-08 & PLSZPTL00010 & 2008-01-09 & PLCASPL00019 & $2013-01-29$ & PLNVMRI00017 \\
\hline 1999-09-10 & PLCOMAR00012 & 2008-01-10 & PLATMSA00013 & 2013-02-18 & PLEFH0000022 \\
\hline 1999-09-15 & PLINTGR00013 & 2008-01-11 & PLSTARK00011 & $2013-02-25$ & PLINTKS00013 \\
\hline 2000-01-04 & PLLETA000018 & 2008-01-31 & PLHDRWL00010 & 2013-03-28 & PLVCAOC00015 \\
\hline 2000-03-06 & PLBRSZW00011 & 2008-02-01 & PLELKOP00013 & 2014-07-03 & PLWLTHB00010 \\
\hline 2000-07-06 & PLSOFTB00016 & $2008-02-21$ & PLZRWZW00012 & 2014-07-08 & PLVGUAR00011 \\
\hline $2000-07-25$ & PLTRAST00020 & $2008-02-22$ & PLINCLT00015 & 2014-09-11 & PLMADKM00019 \\
\hline $2000-09-11$ & PLMITEX00018 & $2008-02-22$ & PLSTLSK00016 & 2014-09-12 & PLDGA0000019 \\
\hline $2000-09-22$ & PLCOMAR00012 & 2008-03-14 & PLATM0000021 & $2014-09-17$ & PLADDRG00015 \\
\hline $2000-12-20$ & PLSKTAN00010 & $2008-04-30$ & PLELZAB00010 & $2014-09-25$ & PLECARD00012 \\
\hline $2001-01-22$ & PLSIMPL00011 & 2008-05-07 & SK1120009230 & $2014-09-25$ & PLNRTHC00014 \\
\hline 2001-03-12 & PLESPBP00014 & $2008-06-16$ & PLDGTAV00013 & 2014-10-01 & PLPEKPL00010 \\
\hline $2002-12-11$ & PLBRSTM00015 & 2008-07-02 & PLERGZB00014 & 2014-10-14 & PLMRKHS00011 \\
\hline 2004-04-26 & PLSMMDA00012 & 2008-08-08 & PLTELL000023 & $2014-10-20$ & PLBLT0000013 \\
\hline 2004-11-05 & PLBRSZW00011 & $2008-10-15$ & PLZBMZC00019 & $2014-10-27$ & PLNTSYS00013 \\
\hline $2005-01-17$ & PLSANWL00012 & $2008-11-14$ & PLJTRZN00011 & $2014-10-27$ & PLINTKS00013 \\
\hline 2005-03-31 & PLDUDA000016 & 2009-07-16 & PLWLTHB00010 & $2014-11-10$ & PLNFI1000012 \\
\hline 2005-03-31 & PLLOTOS00025 & $2009-08-21$ & PLHLDPT00010 & 2014-11-14 & PLINSTL00011 \\
\hline
\end{tabular}




\begin{tabular}{|c|c|c|c|c|c|}
\hline 1 & 2 & 3 & 4 & 5 & 6 \\
\hline 2005-07-01 & PLKROSN00015 & 2009-09-28 & PLIZCJR00017 & 2014-11-19 & PLDRZPL00032 \\
\hline $2005-07-15$ & PLENAP000010 & 2009-11-04 & PLSTARK00011 & $2014-11-24$ & PLMAXMS00010 \\
\hline $2005-07-15$ & PLSTLPF00012 & $2009-11-24$ & PLCHMDW00010 & $2014-11-25$ & PLMCINT00013 \\
\hline $2005-09-30$ & PLZPW0000017 & $2009-12-28$ & PLHRTIM00013 & $2014-12-02$ & PLLSRMD00018 \\
\hline $2005-11-17$ & PLCRSNT00011 & 2010-03-26 & PLLUG0000010 & $2014-12-03$ & PLASMOT00030 \\
\hline 2006-03-10 & PLLUBAW00013 & $2010-04-19$ & PLNCLGM00014 & 2014-12-09 & PLFSTFC00012 \\
\hline $2006-06-26$ & PLBIOTN00029 & $2010-04-29$ & PLGPFCS00018 & 2014-12-11 & PLBSSTM00013 \\
\hline 2006-08-01 & PLKOPEX00018 & 2010-07-09 & PLMLKPL00012 & 2014-12-11 & PLGEINV00017 \\
\hline 2006-08-02 & PLECHPS00019 & 2010-09-08 & PLDVCOM00018 & $2014-12-15$ & PLBDVR000018 \\
\hline 2006-08-09 & PLGTC0000037 & 2010-09-15 & PLAUXLM00026 & $2014-12-15$ & PLTRKPL00014 \\
\hline 2006-08-21 & PLAPATR00018 & $2010-09-15$ & PLAXILA00018 & $2014-12-17$ & PLCMPLX00014 \\
\hline 2006-08-25 & PLELPO000016 & 2010-09-24 & PLSOBET00019 & 2014-12-18 & PLJHMDL00018 \\
\hline 2006-09-07 & PLLZPSK00019 & 2010-09-30 & PLHFLSW00013 & $2014-12-22$ & PLSCOPK00012 \\
\hline $2006-10-23$ & PLUNIML00012 & $2010-10-21$ & PLDFP0000019 & 2015-02-25 & PLIDATF00012 \\
\hline 2006-10-30 & PLSMMDA00012 & $2010-11-10$ & PLPOLMN00010 & 2015-03-13 & PLSTCKI00016 \\
\hline 2006-11-03 & PLELSTO00018 & $2010-11-15$ & PLASSTS00012 & 2015-03-20 & PL4STUD00016 \\
\hline $2006-12-28$ & PLENMPD00018 & 2010-12-08 & PLPBLIA00012 & 2015-03-23 & PLIBZIC00013 \\
\hline $2006-12-29$ & PLTVN0000017 & 2011-03-08 & PLICI0000010 & 2015-05-04 & PLBLKPC00014 \\
\hline $2007-01-25$ & PLGUARD00019 & 2011-04-01 & PLINTNT00015 & 2015-05-29 & PLSWMED00013 \\
\hline 2007-02-08 & PLIDMSA00044 & 2011-04-26 & PLSUWAR00014 & $2015-06-17$ & PLERSNK00016 \\
\hline 2007-03-08 & PLELKOP00013 & 2011-05-30 & PLMNNCP00011 & 2015-06-29 & PLDREWX00012 \\
\hline 2007-03-30 & PLBRSTM00015 & 2011-07-07 & PLEENRG00014 & 2015-08-01 & PLINVNT00011 \\
\hline $2007-05-25$ & PLBYTOM00010 & 2011-07-12 & PLESTHN00018 & $2015-08-10$ & PLWEEDO00019 \\
\hline $2007-06-25$ & PLKRUK000019 & 2011-09-02 & PLCWPE000017 & 2015-09-01 & PLPRNTC00017 \\
\hline $2007-07-12$ & PLHTLST00010 & $2011-10-21$ & PLBOMAX00012 & $2015-11-25$ & PLVCAOC00015 \\
\hline 2007-08-02 & PLFAMUR00012 & 2011-11-18 & PLBSK0000017 & $2015-11-30$ & PLPZU0000011 \\
\hline
\end{tabular}

Źródło: opracowanie własne skompilowane na podstawie na danych z systemu Bloomberg oraz z serwisu Bossa.pl.

\title{
LONG-TERM POST-SPLIT PERFORMANCE ON THE WARSAW STOCK EXCHANGE
}

\begin{abstract}
Purpose - The aim of this paper is to investigate the long-term performance following stock splits on the Warsaw Stock Exchange.

Design/Methodology/approach - The study is based on stock splits conducted on the Warsaw Stock Exchange within years 1996-2015. We formed equal-weighted and capitalization-weighted calendar portfolios with various sorting periods ranging 1-8 years and evaluated their performance with the CAPM and the four-factor model by Carhart (1997).

Findings - We observed no significant abnormal returns and the results are robust to the changes of weighting methods or sorting periods. The examined calendar portfolios displayed significant exposure to the SMB factor. It indicates that the stock splits are largely concentrated in small-cap companies.

Originality/Value - This is the first comprehensive study of the post-split long-term performance on the Warsaw Stock Exchange.
\end{abstract}

Keywords: stock splits, event study, calendar portfolios, long-term performance, Warsaw Stock Exchange, WSE, Polish stock market

\section{Cytowanie}

Okoń, S., Zaremba, A. (2017). Długoterminowe reakcje cenowe na podziały akcji na Giełdzie Papierów Wartościowych w Warszawie. Finanse, Rynki Finansowe, Ubezpieczenia, 2 (86), 111-122. DOI: 10.18276/frfu.2017.86-09. 